ORIGINAL ARTICLE / ARTIGO ORIGINAL

\title{
Changes in total physical activity, leisure and commuting in the largest city in Latin America, 2003-2015
}

\author{
Mudanças na atividade física total, de lazer e deslocamento na maior \\ cidade da América Latina, 2003-2015
}

\begin{abstract}
Tatiane Kosimenko Ferrari Figueiredo' (D), Ricardo Goes de Aguiar ${ }^{(D)}$, Alex Antonio Florindoll (D), Maria Cecília Goi Porto Alves III (D), Marilisa Berti de Azevedo Barros ${ }^{\mathrm{IV}}$ (D), Moisés Goldbaum ${ }^{\mathrm{V}}$ (D), Gerson Ferrariv' (D), Regina Mara Fisberg' (1D, Chester Luiz Galvão Cesar' (1)
\end{abstract}

\begin{abstract}
Objective: To analyze the prevalence of physical inactivity and the average time of practice of total physical activity and by domains (leisure and commuting), according to gender, age group and schooling, between 2003 and 2015, in residents of the urban area of the city of São Paulo. Methods: Data from Household Health Surveys in the Municipality of São Paulo (2003: $n=2,514 ; 2015: n=4,043)$. The International Physical Activity Questionnaire was used to measure total, leisure, and commuting physical activity. Results were presented in < 10 minute/week periods, physical inactivity and minutes/week, according to evaluation period, sex, age and schooling. Results: Prevalence of < 10 minutes/week periods in 2003 and 2015 were: 22.5 and $28.9 \%$ for the total; 56.7 and $58.3 \%$ for leisure; and 35.2 and $39.9 \%$ for commuting, with significant change only in the total item, among adolescents (10.3 to $18.8 \%$ ). For physical inactivity, prevalence rates were: 54.9 and $61.6 \%$ (total); 78.2 and $78.9 \%$ (leisure); and 72 and $79.9 \%$ (commuting), with significant changes only for commuting among adults ( 67.8 to $77.4 \%$ ). For the average in minutes per week, in total, there was a significant decrease for female adolescents (138.2 minute/week) and adults with 0-8 (122.6 minutes/week) and 9-11 years (96.7 minutes/week) years of schooling; in commuting, there was a reduction for female adolescents (95 minutes/ week); and male adults (95 minutes/week) and female adults ( 82 minutes/week). Conclusions: There were no reductions in the prevalence of $<10 \mathrm{~min} /$ week periods or leisure physical inactivity. Commuting physical inactivity has become even more common.
\end{abstract}

Keywords: Motor activity. Sedentary behavior. Epidemiology. Surveillance.

ISchool of Public Health, Universidade de São Paulo - São Paulo (SP), Brazil.

"School of Arts, Sciences and Humanities, Universidade de São Paulo - São Paulo (SP), Brazil.

"IIInstituto de Saúde, Secretaria de Estado da Saúde - São Paulo (SP), Brazil.

Iv School of Medical Sciences, Universidade Estadual de Campinas - Campinas (SP), Brazil.

v'Medical School, Universidade de São Paulo - São Paulo (SP), Brazil.

vEscuela de Ciencias de la Actividad Física, el Deporte y la Salud, Universidad de Santiago de Chile - Santiago, Chile.

Corresponding author: Tatiane Kosimenko Ferrari Figueiredo. Epidemiology Department, School of Public Health, Universidade de São Paulo, located at Avenida Doutor Arnaldo, 715, Cerqueira César, CEP: 01246-904, São Paulo, SP, Brazil. E-mail: tatianekferrari@yahoo.com.br

Conflict of interests: nothing to declare - Financial support: Coordenação de Aperfeiçoamento de Pessoal de Nível Superior (CAPES), Conselho Nacional de Desenvolvimento Científico e Tecnológico (CNPq) and Secretaria Municipal de Saúde de São Paulo. 
RESUMO: Objetivo: Analisar a prevalência de inatividade física e o tempo médio de prática de atividade física total e por domínios (lazer e deslocamento), de acordo com sexo, faixa etária e escolaridade, em residentes de área urbana do munícipio de São Paulo, entre os anos de 2003 e 2015. Métodos: Utilizaram-se dados dos Inquéritos Domiciliares de Saúde no Município de São Paulo (2013: $\mathrm{n}=2.514 ; 2015: \mathrm{n}=4.043)$. O International Physical Activity Questionnaire foi utilizado para mensurar a atividade física total, de lazer e deslocamento. Resultados foram apresentados em períodos de $<10$ minutos/semana, inatividade física e minutos/semana, conforme período de avaliação, faixa etária, sexo e escolaridade. Resultados: As prevalências dos períodos < 10 minutos/semana em 2003 e 2015 foram 22,5 e 28,9\% para total; 56,7 e 58,3\% para lazer; e 35,2 e 39,9\% para deslocamento, com mudança significativa no total em adolescentes, de 10,3 para 18,8\%. Para inatividade física, as prevalências foram 54,9 e $61,6 \%$ para total; 78,2 e 78,9\% para lazer; e 72 e 79,9\% para deslocamento, com mudanças significativas no deslocamento em adultos, de 67,8 para $77,4 \%$. Para as médias de atividade física total, houve diminuição significativa para adolescentes do sexo feminino (138,2 minutos/semana) e adultos com escolaridade de 0-8 (122,6 minutos/semana) e 9-11 anos (96,7 minutos/semana); no deslocamento, houve diminuição para adolescentes do sexo feminino (95 minutos/semana) e adultos do sexo masculino (95 minutos/semana) e feminino (82 minutos/ semana). Conclusão: Não foram encontradas diminuições na prevalência dos períodos $<10$ minutos/semana e na inatividade física no lazer. A inatividade física no deslocamento ficou ainda maior.

Palavras-chave: Atividade física. Comportamento sedentário. Epidemiologia. Vigilância.

\section{INTRODUCTION}

Although the benefits of regular physical activity (PA) are indicated and disseminated, physical inactivity is still one of the main risk factors for the development of chronic diseases and mortality from all causes ${ }^{1-3}$.

Compliance with current PA recommendations, or even PA performance in continuous periods of at least 10 minutes per week, is absolutely essential to improve health and prevent chronic non-communicable diseases in all age groups, ethnicities and levels of schooling $^{1}$. However, evidence ${ }^{4,5}$ has shown that some population strata have greater opportunities to reach the recommendations for the practice of PA. In Brazil, the Surveillance System for Risk and Protective Factors for Chronic Diseases by Telephone Survey (VIGITEL) has revealed that men, and those with 9 years or more of schooling, practice more leisure PA than women and those with 8 or less years of schooling 4 .

One area of interest in public health is to know in which domains people are more or less physically active, or whether or not they practice physical activity. The assessment of PA patterns by domains might provide a more complete understanding of this complex behavior, since the different domains of PA are influenced by different factors ${ }^{6,7}$.

Promoting PA in residents of large cities is an even greater challenge. São Paulo is among the ten most urbanized cities in the world ${ }^{8}$, characterized by several different cultural and socioeconomic origins; besides, the city still offers a wide variety when it comes to the 
distribution of diseases and lifestyles. In recent years, the city of São Paulo has undergone a strong urbanization process, in addition to a demographic, epidemiological and socioeconomic transition ${ }^{9}$. However, disorganized traffic, rising criminality rates and social inequality still persist ${ }^{9}$, facts that produce changes in PA patterns at all ages ${ }^{10,11}$.

Systematic reviews indicate that most studies on the regular practice of PA have been carried out in high-income countries ${ }^{12,13}$. In Brazil, an increase in the practice of leisure-time PA was observed between 2006 and 2016 among women and in those with more schooling, when compared to men and those with less schooling ${ }^{4}$. However, few studies have shown the total PA pattern and domain in adolescents, adults and the elderly who live in metropolises in low- and middle-income countries ${ }^{14}$.

In the urban context of the city of São Paulo, characterized by social fragmentation and inequalities in opportunities to perform PA, the New Master Plan emerged as an effective initiative to promote PA, increasing the network of cycle paths in the city ${ }^{15}$. Bike paths represent an opportunity to encourage the equitable and sustainable use of public spaces, because they have the potential to change the behavioral attitudes of commuting $\mathrm{PA}^{16}$.

Therefore, understanding PA patterns by domain, age group, sex, educational level in two-time periods in the largest city in Latin America can provide new information on how policies and interventions affect $\mathrm{PA}^{17,18}$.

Thus, the objective of the present study was to analyze the prevalence of physical inactivity and the average time of practice of total PA and by domains (leisure and commuting), according to sex, age group and schooling in residents of the urban area of the city of São Paulo, between the years 2003 and 2015.

\section{METHODS}

\section{STUDY DESIGN}

This is a cross-sectional, population-based study that used data from Household Health Surveys in the city of São Paulo (ISA-Capital) from 2003 to 2015, in which the study sample referred to the population living in the urban area of the city of São Paulo. ISA was carried out with the objective of evaluating the health status of the population in the city, according to their living conditions and addressing lifestyle indicators and chronic diseases $^{19}$. In the city of São Paulo, editions were prepared in 2001, 2003, 2008 and 2015. The survey was conducted by researchers from the public universities in São Paulo and in the São Paulo State Health Department. For the population of the present study, individuals of both sexes, adolescents (12-19 years-old), adults (20-59 years-old) and the elderly ( $\geq 60$ years-old) were selected, totaling 2,514 participants in 2003 and 4,043 in 2015. In both assessment periods, stratified probability samples were used, with a two-stage random selection: census tracts and households. In 2003, six stratification groups were considered, according to their age and gender: infants younger than 1 year of age (regardless of sex), 1 to 11 year-old children (regardless of sex), 12 to 19 year-old female teens, 20 to 
59 year-old women, 60 year-old or older women, 12 to 19 year-old male teens, 20 to 59 year-old men and 60 year-old or older men.

It was determined that the total sample would be formed by 3,360 people, with 420 interviews per group. In each census sector, there was a plan to obtain seven interviews per interest group. In order to prevent the loss of $20 \%$ of sample units due to non-response, 8.75 people were selected randomly in each group $(7 / 0.8=8.75)$. Thus, a minimum number of 420 interviews were defined in each of the study groups, making it possible to estimate proportions of 0.50 , with a sampling error of 0.058 , considering a $95 \%$ confidence level and a design effect of 1.5 .

Referring to 2015, 20 stratification groups were analyzed according to their age, sex and five regional health coordination sites (North, Midwest, Southeast, South and East areas): from 12 to 19 year-old subjects (regardless of gender), 20 to 59 year-old women, 20 to 59 year-old men and 60 year-old or older individuals (regardless of gender) in each of the five regional health coordination aforementioned sites. It was determined that the total sample would be formed of 4,250 people. A minimum number of 150 interviews was defined in each of the study groups, making it possible to estimate proportions of 0.50 , with a sampling error of 0.10 , considering a $95 \%$ confidence level and a design effect of 1.5 . All of the selected households were visited at least three times.

The response rate per household was 0.76 and, after interviewing the eligible population contacted in these households, the response rate was 0.74 . In total, 4,043 interviews were carried out. More details on the complete sampling process had been published previously ${ }^{20}$.

Participants who did not live in the city and in the household, homeless people, institutionalized individuals and subjects younger than the age of interest were excluded from the trial. The surveys are similar, but the sampling plans that were used during two years have different aspects due to the interest in improving the data collection process, based on acquired experiences. Even so, the possibility of comparing the various editions was preserved. All participants or the people responsible for the events signed the Informed Consent Form. The study was approved by the Human Research Ethics Committee at the School of Public Health at Universidade de São Paulo (no 2.667.916).

\section{PHYSICAL ACTIVITY}

For the evaluation of PA, the long version of the International Physical Activity Questionnaire (IPAQ) was used referring to the activities practiced in the last seven days ${ }^{21}$. The IPAQ is validated to analyze the PA of people aged 14 years or older ${ }^{21-23}$. Only the domains of leisure and commuting were included in the present study, due to their greater relevance to guide public health policies and programs ${ }^{24}$.

The data were analyzed for the time spent separately in the PA domains during leisure and commuting and for total PA time. For the definition of total PA, the sum of leisure and commuting time was considered. For leisure-time PA, the weekly frequency and duration 
(of at least 10 continuous minutes) of walking, moderate PA and vigorous PA were analyzed. For PA during commuting, the weekly frequency and duration (of at least 10 continuous minutes) of walking and using a bicycle for commuting purposes were analyzed. Based on these PA practice scores, the results were presented in three forms: duration $<10$ min / week (categorical — did not practice at least 10 minutes of PA for total physical activity and by domains), physical inactivity (categorical — did not reach international PA recommendations, considering the total practice time and for the domains that were analyzed) and min / week (continuous - average practice time, in minutes per week).

The cut-off point $<10 \mathrm{~min} /$ week of PA was used for the following reasons:

- minimum duration considered in the IPAQ questions ${ }^{1}$;

- practicing at least $10 \mathrm{~min} /$ week of continuous PA (per domain or total) reduces the risk of cardiovascular diseases, obesity and mortality from all causes ${ }^{1,25,26}$;

- moderate correlation with objective PA measures $(r=0.44)^{27}$.

In order to comply with the recommendations, a cut-off point of $150 \mathrm{~min} /$ week was used for people aged 18 or older, and a cut-off point of $420 \mathrm{~min} /$ week (60 $\mathrm{min} / \mathrm{day}$ ) for people aged between 12 and 17 years, according to current PA recommendations ${ }^{1}$.

In general, international PA recommendations are related to total PA, which include the four domains ${ }^{20}$.

However, the results were presented separately for the domains of leisure and Commuting, and the sum of both, due to their relevance for the elaboration of public policies and the different relations with cardiovascular diseases ${ }^{28,29}$.

\section{INDEPENDENT VARIABLES}

For the independent variables, the study participants were categorized according to sex (male or female) and schooling (0-8, 9-11 or $\geq 12$ years of schooling). The respondent's schooling for adults ( $\geq 20$ years) and the schooling of the head of the family for adolescents (12-19 years) were also considered.

\section{STATISTICAL ANALYSIS}

For data analysis, average, standard deviation and 95\% confidence intervals (95\%CI) of PA in min. / week were calculated according to age group, sex and education. All comparisons were made by analyzing the overlaps of $95 \% \mathrm{CI}$, with a significant difference being considered when there was no overlap of the $95 \% \mathrm{CI}^{30}$; and no difference was considered when one of the $95 \% \mathrm{CI}$ was partially included by the other.

The Stata statistical package (Stata, version 14, StataCorp, College Station, Texas, USA) was used, which allowed the incorporation of aspects related to the complex sample design — strata, clusters and considerations - through the survey module. 


\section{RESULTS}

In 2003, 846 participants were excluded from the study due to the exclusion criteria ( $\mathrm{n}=2,514-$ adolescents, $\mathrm{n}=847$; adults, $\mathrm{n}=795$; elderly, $\mathrm{n}=872$ ), since this sample also included 1 year-old infants. In 2015, there was no loss of participants ( $n=4,043$ - adolescents, $\mathrm{n}=859$; adults, $\mathrm{n}=2,165$; elderly, $\mathrm{n}=1,019$ ). The proportion of adolescents was similar between the sexes in both assessment periods (male $50.8 \%$ and female $49.2 \%$, in 2003; male $50.6 \%$ and female $49.4 \%$, in 2015). Among adults and the elderly, the proportion was higher in women both in 2003 (adults: male $46.1 \%$ and female $53.9 \%$; elderly: male $39.7 \%$ and female $60.3 \%$ ) and in 2015 (adults: male $47.6 \%$ and female $52.4 \%$; elderly: male $40.3 \%$; female $59.7 \%$ ).

The prevalence of periods $<10 \mathrm{~min} /$ week in 2003 and in 2015 was: 22.5 and $28.9 \%$ for total PA; 56.7 and $58.3 \%$ for leisure PA; and 35.2 and $39.9 \%$ for commuting PA. A significant increase in the prevalence of periods $<10 \mathrm{~min} /$ week was found only in the total PA of adolescents (from 10.3 to 18.8\%). No significant changes were found in leisure-time and commuting PA of adolescents, adults and the elderly, or in the total PA of adults and the elderly. In other words, the prevalence of people who do not perform the minimum of continuous PA (to be considered in the weekly score) did not changed in these groups and was even higher for the total PA of adolescents (Table 1).

Table 1. Prevalence of periods $<10 \mathrm{~min} /$ week of total physical activity, during leisure and commuting. ISA-Capital 2003 and 2015, São Paulo, Brazil.

\begin{tabular}{|c|c|c|c|c|c|c|}
\hline \multirow{2}{*}{ Independent variables } & \multicolumn{3}{|c|}{$2003(n=2,514)$} & \multicolumn{3}{|c|}{$2015(n=4,043)$} \\
\hline & $\%$ & \multicolumn{2}{|c|}{$95 \% \mathrm{Cl}$} & $\%$ & \multicolumn{2}{|c|}{$95 \% \mathrm{Cl}$} \\
\hline \multicolumn{7}{|l|}{ Adolescents } \\
\hline$<10 \mathrm{~min} / \mathrm{wk}$ in total & 10.3 & 7.7 & 13.8 & 18.8 & 15.1 & 23.3 \\
\hline$<10 \mathrm{~min} / \mathrm{wk}$ in leisure & 38.4 & 33.1 & 44.1 & 44.1 & 39.6 & 48.6 \\
\hline$<10 \mathrm{~min} / \mathrm{wk}$ in commuting & 24.2 & 18.1 & 31.7 & 30.1 & 25.7 & 34.8 \\
\hline \multicolumn{7}{|l|}{ Adults } \\
\hline$<10 \mathrm{~min} / \mathrm{wk}$ in total & 22.3 & 19.1 & 25.9 & 28.5 & 25 & 32.2 \\
\hline$<10 \mathrm{~min} / \mathrm{wk}$ in leisure & 63 & 58.7 & 67.1 & 65.9 & 62.7 & 69.1 \\
\hline$<10 \mathrm{~min} / \mathrm{wk}$ in commuting & 35.6 & 30.4 & 41.2 & 39.3 & 35.7 & 43.1 \\
\hline \multicolumn{7}{|l|}{ Elderly } \\
\hline$<10 \mathrm{~min} / \mathrm{wk}$ in total & 34.9 & 30.7 & 39.3 & 39.6 & 35.5 & 43.7 \\
\hline$<10 \mathrm{~min} / \mathrm{wk}$ in leisure & 68.9 & 64 & 73.3 & 69.1 & 64.8 & 73 \\
\hline$<10 \mathrm{~min} /$ wk in commuting & 45.7 & 40.9 & 50.6 & 50.3 & 45.9 & 54.7 \\
\hline
\end{tabular}

ISA-SP: Household Health Surveys in the city of São Paulo; \%: prevalence; $95 \% \mathrm{Cl}$ : $95 \%$ confidence interval. 
The prevalence of physical inactivity in 2003 and in 2015 was: 54.9 and $61.6 \%$ for total PA; 78.2 and $78.9 \%$ for leisure-time PA; and 72 and $79.9 \%$ for commuting PA. A significant increase in the prevalence of physical inactivity was found only in the commuting PA of adults (from 67.8 to $77.4 \%$ ). No significant changes were seen in leisure-time PA and total among adolescents, adults and the elderly, or in the commuting PA of adolescents and the elderly (Table 2).

The average of total PA was $341 \mathrm{~min} /$ week in 2003 and $283.6 \mathrm{~min} /$ week in 2015.

Significant decrease in total PA was found among female adolescents (358.8 and 220.6), in adults in general (320.9 and 264.7), female adults (251.3 and 210.9) and in adults with 0-8 (298.6 and 176.4) and 9-11 years of schooling (357.7 and 261) (Table 3).

The average of leisure-time PA was $161.9 \mathrm{~min} /$ week in 2003 and $164.7 \mathrm{~min} /$ week in 2015. There were no significant changes in leisure-time PA in the total sample, by age grup, sex or education (Table 4).

The average of PA during commuting was $179.6 \mathrm{~min} /$ week in 2003 and $118.9 \mathrm{~min} /$ week in 2015. Significant decrease in PA during commuting was shown only among female adolescents (201 and $106 \mathrm{~min} /$ week) and in male (222.7 and $125.5 \mathrm{~min} /$ week) and female adults (174.6 and $92.6 \mathrm{~min} /$ week). No significant changes were found in relation to schooling (Table 5).

Table 2. Prevalence of total physical inactivity, during leisure and commuting. ISA-Capital 2003 and 2015, São Paulo, Brazil.

\begin{tabular}{|c|c|c|c|c|c|c|}
\hline \multirow{2}{*}{ Independent variables } & \multicolumn{3}{|c|}{2003} & \multicolumn{3}{|c|}{2015} \\
\hline & $\%$ & \multicolumn{2}{|c|}{$95 \% \mathrm{Cl}$} & $\%$ & \multicolumn{2}{|c|}{$95 \% \mathrm{Cl}$} \\
\hline \multicolumn{7}{|l|}{ Adolescents } \\
\hline physical inactivity in total & 60 & 55.1 & 64.7 & 66.2 & 61.6 & 70.5 \\
\hline physical inactivity at leisure & 76.2 & 73.1 & 79 & 79.3 & 75.1 & 83 \\
\hline physical inactivity in commuting & 82.5 & 78.6 & 85.8 & 87.2 & 84.1 & 90 \\
\hline \multicolumn{7}{|l|}{ Adults } \\
\hline physical inactivity in total & 51.9 & 48 & 55.8 & 58.7 & 55.3 & 62 \\
\hline physical inactivity at leisure & 78.1 & 74 & 81.7 & 77.7 & 75.2 & 80 \\
\hline physical inactivity in commuting & 67.8 & 63.4 & 71.9 & 77.4 & 74.5 & 80 \\
\hline \multicolumn{7}{|l|}{ Elderly } \\
\hline physical inactivity in total & 63.2 & 58.8 & 67.5 & 70.3 & 66.4 & 73.9 \\
\hline physical inactivity at leisure & 81.6 & 78.4 & 84.2 & 84.1 & 81 & 86.7 \\
\hline physical inactivity in commuting & 78.9 & 74.1 & 83.1 & 84.8 & 81.7 & 87.5 \\
\hline
\end{tabular}

ISA-SP: Household Health Surveys in the city of São Paulo; \%: prevalence; $95 \% \mathrm{Cl}$ : 95\% confidence interval; physical inactivity: non-compliance with international recommendations for physical activity ( $420 \mathrm{~min} /$ week for the population aged 12-17 year and $150 \mathrm{~min} /$ week for the population aged $\geq 18$ year). 
Table 3. Average time of total physical activity ( $\mathrm{min} /$ week), according to age group, sex and education. ISA-Capital 2003 and 2015, São Paulo, Brazil.

\begin{tabular}{|c|c|c|c|c|c|c|c|c|c|}
\hline \multicolumn{2}{|c|}{ Independent variables } & \multirow{2}{*}{$\begin{array}{c}\bar{x} \\
490.6\end{array}$} & \multirow{2}{*}{$\begin{array}{c}\Sigma \\
34.5\end{array}$} & \multicolumn{2}{|c|}{$95 \% \mathrm{Cl}$} & \multirow{2}{*}{$\begin{array}{c}\bar{x} \\
417.8\end{array}$} & \multirow{2}{*}{$\begin{array}{c}\Sigma \\
29.6\end{array}$} & \multicolumn{2}{|c|}{$95 \% \mathrm{Cl}$} \\
\hline Adolescents & Total & & & 421.6 & 559.7 & & & 359.2 & 476.4 \\
\hline \multirow{2}{*}{ Sex } & Male & 619.5 & 47.4 & 524.5 & 714.6 & 610.4 & 47.4 & 516.5 & 704.3 \\
\hline & Female & 358.8 & 41 & 276.5 & 441.1 & 220.6 & 18.7 & 183.6 & 257.6 \\
\hline \multirow{3}{*}{ Education } & $0-8$ years & 506.4 & 44 & 418.2 & 594.7 & 403.3 & 48.4 & 307.1 & 499.4 \\
\hline & $9-11$ years & 468.5 & 77.5 & 312.4 & 624.6 & 455.7 & 53.1 & 350.2 & 561.2 \\
\hline & $\geq 12$ years & 475.9 & 64.8 & 345.2 & 606.6 & 374.5 & 55.5 & 263.4 & 485.7 \\
\hline Adults & Total & 320.9 & 19.6 & 281.7 & 360.1 & 264.7 & 14.1 & 236.7 & 292.6 \\
\hline \multirow{2}{*}{ Sex } & Male & 402.2 & 29.6 & 342.9 & 461.5 & 323.8 & 22.1 & 280 & 367.6 \\
\hline & Female & 251.3 & 26.8 & 197.6 & 304.9 & 210.9 & 16.1 & 179 & 242.8 \\
\hline \multirow{3}{*}{ Schooling } & $0-8$ years & 298.6 & 28.1 & 242.3 & 355 & 176.4 & 13.9 & 148.8 & 204.1 \\
\hline & $9-11$ years & 357.7 & 31.2 & 295 & 420.4 & 261 & 18.4 & 224.7 & 297.4 \\
\hline & $\geq 12$ years & 301.1 & 42.7 & 214.4 & 387.7 & 371.2 & 39.9 & 292.2 & 450.2 \\
\hline Elderly & Total & 211.6 & 23.6 & 164.3 & 259 & 168.2 & 18.5 & 131.5 & 204.8 \\
\hline \multirow{2}{*}{ Sex } & Male & 277.8 & 40.4 & 196.9 & 358.7 & 232.2 & 39.8 & 153.5 & 310.8 \\
\hline & Female & 168.1 & 23.5 & 120.9 & 215.2 & 124.9 & 13.1 & 99 & 150.9 \\
\hline \multirow{3}{*}{ Schooling } & $0-8$ years & 186.7 & 21.3 & 144 & 229.5 & 130.1 & 12.9 & 104.5 & 155.6 \\
\hline & 9-11 years & 178.2 & 26.2 & 125.2 & 231.2 & 172.7 & 23.6 & 125.7 & 219.6 \\
\hline & $\geq 12$ years & 383.2 & 74.5 & 229.5 & 537.1 & 285.7 & 68.6 & 148.3 & 423.2 \\
\hline
\end{tabular}

ISA-SP: Household Health Surveys in the city of São Paulo; $\bar{x}$ : average; $\sigma$ : standard deviation; $95 \%$ Cl: 95\% confidence interval.

Table 4. Average time of leisure physical activity ( $\mathrm{min} /$ week), according to age group, sex and education. ISA-Capital 2003 and 2015, São Paulo, Brazil.

\begin{tabular}{l|c|c|c|c|c|c|c|c|c|}
\hline \multirow{2}{*}{ Independent variables } & $\bar{x}$ & $\sigma$ & \multicolumn{2}{|c|}{$95 \% \mathrm{Cl}$} & $\bar{x}$ & $\sigma$ & \multicolumn{2}{|c}{$95 \% \mathrm{Cl}$} \\
\hline Adolescents & Total & 273.1 & 19.4 & 234.2 & 312 & 256.9 & 22.2 & 212.9 & 300.9 \\
\hline \multirow{3}{*}{ Sex } & Male & 385.9 & 31.7 & 322.4 & 449.4 & 395.9 & 37.5 & 321.6 & 470.3 \\
\hline \multirow{3}{*}{ Schooling } & Female & 157.8 & 16.9 & 123.8 & 181.7 & 114.6 & 13.6 & 87.7 & 141.6 \\
\hline \multirow{3}{*}{ Adults } & $0-8$ years & 249.6 & 25.4 & 198.6 & 300.7 & 241.1 & 34.3 & 173 & 309.2 \\
\hline \multirow{2}{*}{ Sex } & $9-11$ years & 273.4 & 49.4 & 174 & 372.8 & 272.8 & 38.5 & 196.3 & 349.2 \\
\cline { 2 - 10 } & $\geq 12$ years & 337.7 & 36.6 & 263.9 & 411.6 & 250.7 & 44.6 & 161.3 & 340 \\
\hline & Total & 124.4 & 14.8 & 94.8 & 153.9 & 156.4 & 12.0 & 132.6 & 180.1 \\
\hline & Male & 179.5 & 25.3 & 128.8 & 230.3 & 198.3 & 17.8 & 163 & 233.5 \\
\hline & Female & 77.1 & 12.2 & 52.6 & 101.6 & 118.3 & 15.0 & 88.6 & 148 \\
\hline
\end{tabular}


Table 4. Continuation.

\begin{tabular}{|l|c|c|c|c|c|c|c|c|c|}
\hline \multirow{2}{*}{ Independent variables } & $\bar{x}$ & $\sigma$ & \multicolumn{2}{|c|}{$95 \% \mathrm{Cl}$} & $\bar{x}$ & $\sigma$ & \multicolumn{2}{|c}{$95 \% \mathrm{Cl}$} \\
\hline \multirow{3}{*}{ Schooling } & $0-8$ years & 77.4 & 12.7 & 51.9 & 102.9 & 74.6 & 11.7 & 51.3 & 97.8 \\
\cline { 2 - 11 } & $9-11$ years & 149.3 & 23.7 & 101.7 & 196.8 & 150.8 & 15.5 & 120.1 & 181.5 \\
\cline { 2 - 10 } & $\geq 12$ years & 186.1 & 28.7 & 127.9 & 244.3 & 261 & 37.4 & 186.9 & 335.2 \\
\hline \multirow{2}{*}{ Elderly } & Total & 88.2 & 13 & 62.1 & 114.2 & 80.7 & 10.2 & 60.5 & 100.9 \\
\hline \multirow{2}{*}{ Sex } & Male & 130 & 21 & 88 & 172 & 114.1 & 21.1 & 72.3 & 155.9 \\
\hline \multirow{3}{*}{ Schooling } & Female & 60.7 & 11.4 & 37.9 & 83.5 & 58.1 & 7.9 & 42.6 & 73.7 \\
\cline { 2 - 10 } & 0-8 years & 78 & 12.2 & 53.5 & 102.5 & 55 & 9.9 & 35.4 & 74.6 \\
\cline { 2 - 9 } & $9-11$ years & 61.1 & 11.7 & 37.4 & 84.8 & 85.9 & 13.2 & 59.8 & 112 \\
\cline { 2 - 9 } & $\geq 12$ years & 164.1 & 44.3 & 72.7 & 255.6 & 157.2 & 35.0 & 87.1 & 227.3 \\
\hline
\end{tabular}

ISA-SP: Household Health Surveys in the city of São Paulo; $\bar{x}$ average; $\sigma$ : standard deviation; $95 \% \mathrm{Cl}$ : $95 \%$ confidence interval.

Table 5. Average time of physical activity during commuting (min / week), according to age group, sex and education. ISA-Capital 2003 and 2015, São Paulo, Brazil.

\begin{tabular}{|c|c|c|c|c|c|c|c|c|c|}
\hline \multicolumn{2}{|c|}{ Independent variables } & \multirow{2}{*}{$\begin{array}{c}\bar{x} \\
218.5\end{array}$} & \multirow{2}{*}{$\begin{array}{c}\sigma \\
22.3\end{array}$} & \multicolumn{2}{|c|}{$95 \% \mathrm{Cl}$} & \multirow{2}{*}{$\begin{array}{c}\bar{x} \\
161.1\end{array}$} & \multirow{2}{*}{$\begin{array}{c}\Sigma \\
14.3\end{array}$} & \multicolumn{2}{|c|}{$95 \% \mathrm{Cl}$} \\
\hline Adolescents & Total & & & 173.8 & 263.1 & & & 132.8 & 189.4 \\
\hline \multirow{2}{*}{ Sex } & Male & 235.6 & 26.4 & 182.8 & 288.5 & 215.1 & 24.8 & 165.8 & 264.3 \\
\hline & Female & 201 & 30.1 & 140.8 & 261.3 & 106 & 93 & 87.5 & 124.5 \\
\hline \multirow{3}{*}{ Schooling } & $0-8$ years & 257.4 & 30.8 & 195.5 & 319.2 & 162.2 & 27 & 108.5 & 215.9 \\
\hline & $9-11$ years & 195.1 & 34.7 & 125.1 & 265 & 183.6 & 26 & 131.9 & 235.4 \\
\hline & $\geq 12$ years & 140.2 & 35 & 69.7 & 210.7 & 123.9 & 20.2 & 83.4 & 164.3 \\
\hline Adults & Total & 196.8 & 17.5 & 161.8 & 231.8 & 108.3 & 5.2 & 97.9 & 118.7 \\
\hline \multirow{2}{*}{ Sex } & Male & 222.7 & 21.3 & 180 & 265.3 & 125.5 & 9.6 & 106.6 & 144.5 \\
\hline & Female & 174.6 & 23.6 & 127.4 & 221.8 & 92.6 & 5 & 82.7 & 102.5 \\
\hline \multirow{3}{*}{ Schooling } & $0-8$ years & 221.9 & 27.3 & 167 & 276.7 & 101.9 & 10.3 & 81.6 & 122.2 \\
\hline & $9-11$ years & 208.4 & 27.3 & 153.6 & 263.2 & 110.2 & 6.2 & 97.9 & 122.5 \\
\hline & $\geq 12$ years & 114.9 & 24.1 & 66.1 & 163.7 & 101.1 & 12.3 & 85.8 & 134.4 \\
\hline Elderly & Total & 123.5 & 13.9 & 95.7 & 151.3 & 87.5 & 11.3 & 65.2 & 109.7 \\
\hline \multirow{2}{*}{ Sex } & Male & 148 & 23.1 & 101.7 & 194.3 & 118 & 23.5 & 71.5 & 164.6 \\
\hline & Female & 107.4 & 16.3 & 74.7 & 140.1 & 66.8 & 8.5 & 50 & 83.5 \\
\hline \multirow{3}{*}{ Schooling } & $0-8$ years & 108.8 & 12.3 & 84.1 & 133.5 & 75.1 & 8.1 & 59.1 & 91 \\
\hline & $9-11$ years & 117.1 & 23.6 & 69.2 & 165 & 86.8 & 16.2 & 54.6 & 119 \\
\hline & $\geq 12$ years & 219.1 & 46.2 & 123.7 & 314.4 & 128.5 & 39 & 50.4 & 206.6 \\
\hline
\end{tabular}

ISA-SP: Household Health Surveys in the city of São Paulo; $\bar{x}$ : average; $\sigma$ : standard deviation; $95 \% \mathrm{Cl}$ : $95 \%$ confidence interval. 


\section{DISCUSSION}

The aim of the present study was to analyze the prevalence of physical inactivity and the average time of practice of total PA and by domains (leisure and commuting) according to sex, age group and schooling of residents of the city of São Paulo between 2003 and 2015. The prevalence of periods $<10 \mathrm{~min} /$ week for total PA increased only among adolescents and no significant changes were found in leisure and commuting PA at any age group. As for the prevalence of physical inactivity, significant increase was shown only for commuting PA in adults. For the average of total PA (min/week), significant decrease was found in female adolescents, adults in general, specifically in female adults, and in adults with $0-8$ and 9-11 years of schooling. The average ( $\mathrm{min} /$ week) leisure PA did not show significant changes. As for the average commuting PA, significant decrease was only found in female adolescents and in adults of both sexes.

São Paulo has been described as a metropolis with a large and disorganized urban expansion. In recent years, there has been an increase in violence and a reduction of open public spaces $^{5,9}$. These facts may explain the higher prevalence of physical inactivity in its population compared to other regions ${ }^{18}$. However, in recent years different interventions have tried to change this scenario. In 2014, the city new Master Plan was implemented to reduce environmental inequities ${ }^{18}$.

Afterwards, programs such as Ruas de Lazer (Leisure Streets) were implemented, in which the streets are closed for car traffic and open to population. There were also programs such as Ciclofaixas de Lazer (Leisure Cycle Paths), in which part of the streets and avenues are open exclusively to cyclists. Finally, green areas such as squares and parks have also been expanded and valued as important public spaces for $\mathrm{PA}^{18}$.

Corroborating evidence from other studies ${ }^{31,32}$, the patterns of total PA in leisure and commuting were higher among male individuals. Men tend to participate more frequently in high-intensity PA, whereas women are more likely to be involved in light to moderate activities ${ }^{33}$.

In addition, men report greater social and friends' support, fewer barriers to involvement and a greater perception of self-efficacy for $\mathrm{PA}^{34}$.

Women, on the other hand, show more negative attitudes towards PA and perceive a less favorable environment for its practice ${ }^{35}$. Interventions in PA, especially in leisure, are important to increase the total PA of women, and it is necessary to identify the preferences, reasons and barriers faced by women to participate in these activities.

Differently from what was found in this trial, the practice of PA in adults' leisure has increased in the last $20-30$ years $^{36}$.

These results were also consistent with those identified in studies carried out in high-income countries ${ }^{37-39}$.

As for PA in commuting, data derive from various sources, such as population studies and transport surveys, but comparing information from different countries is difficult, as the instruments are not standardized and various types of indicators are used, such as active commuting for school or work, PA on commuting, walking and cycling. In addition, 
in general, data for time trends in PA in low- and mid-income countries are scarce and, when available, they are inconsistent ${ }^{40}$.

The study by Guthold et al. ${ }^{32}$ assessed the prevalence of physical inactivity in populations from 168 countries in 2001 and in 2016. The prevalence of physical inactivity was $27.5 \%$ in 2016 , with a difference between genders $(23.4 \%$ for male and $31.7 \%$ for female participants), and the prevalence of physical inactivity remained stable between 2001 and 2016.

As in the present study, the results did not show any changes in relation to physical inactivity during the evaluation periods, with the results being even worse in the case of female participants and those with less schooling.

In order to improve the population's PA levels, the Ministry of Health has been financing the development of community interventions in several cities. In 2006, the National Health Promotion Policy ${ }^{41}$ was launched and, in 2012, the Brazilian Strategic Plan to Combat Chronic Non-communicable Diseases was implemented, and is effective until 2022 $2^{42,43}$. Both interventions offer free classes, facilitate the access to gym facilities and provide equipment for the practice of $\mathrm{PA}^{44}$.

However, despite the current scenario, with the efforts and interventions already in place, the results of the present study show that the levels of PA and physical inactivity have not changed. These interventions are likely to increase public awareness as to the importance of PA for health, but have not yet been effective in changing behavior and promoting increased PA.

Although this study has a population-based sample with two evaluation points, some limitations must be considered: the use of an indirect method for assessing PA, which may under or overestimate the quality and quantity of PA performed; due to the low / moderate validity of the IPAQ for adolescents, it is necessary to exercise caution when interpreting the results for this group ${ }^{45}$; the results of the present study are valid only for the urban areas in the city of São Paulo.

After more than a decade, there were no significant changes in the prevalence of periods of $<10 \mathrm{~min}$ / week for leisure, commuting and total PA. Regarding the prevalence of physical inactivity, significant increase was found only for commuting PA in adults.

The average (min / week) PA during leisure did not change significantly between the two evaluation periods. As for the average commuting PA, significant decrease was found only in female adolescents and adults of both sexes. For total PA ( $\mathrm{min} / \mathrm{week}$ ), significant reduction was seen in these groups: female adolescents, adults in general, specially female adults, adults with $0-8$ and $9-11$ years of schooling. This information is essential for improving existing policies and programs, mainly due to the possibility of giving greater attention to the groups that have been identified in the present study with the most worrying results.

\section{ACKNOWLEDGMENTS}

We would like to thank all the researchers of the Household Health Surveys in the city of São Paulo. 


\section{REFERENCES}

1. U.S. Department of Health and Human Services. Physical Activity Guidelines for Americans. $2^{\mathrm{a}} \mathrm{ed}$. Washington, D.C.: U.S. Department of Health and Human Services; 2018.

2. O’Donovan G, Lee IM, Hamer M, Stamatakis E. Association of "Weekend Warrior" and Other Leisure Time Physical Activity Patterns With Risks for AllCause, Cardiovascular Disease, and Cancer Mortality. JAMA Intern Med 2017; 177(3): 335-42. https:// doi. org/10.1001/jamainternmed.2016.8014

3. Ekelund U, Tarp J, Steene-Johannessen J, Hansen $\mathrm{BH}$, Jefferis B, Fagerland MW, et al. Dose-response associations between accelerometry measured physical activity and sedentary time and all cause mortality: systematic review and harmonised meta-analysis. BMJ 2019; 366: 14570. https: / / doi.org/10.1136/bmj.14570

4. Cruz MSD, Bernal RTI, Claro RM. [Trends in leisuretime physical activity in Brazilian adults (2006-2016)]. Cad Saude Publica 2018; 34(10): e00114817. https: / / doi.org/10.1590/0102-311x00114817

5. Ferrari G, Rezende LFM, Wagner GA, Florindo AA, Peres MFT. Physical activity patterns in a representative sample of adolescents from the largest city in Latin America: a cross-sectional study in São Paulo. BMJ Open 2020; 10(9): e037290. https: / / doi.org/10.1136/ bmjopen-2020-037290

6. Sugiyama T, Cerin E, Owen N, Oyeyemi AL, Conway TL, Van Dyck D, et al. Perceived neighbourhood environmental attributes associated with adults recreational walking: IPEN Adult study in 12 countries. Health Place 2014; 28: 22-30. https: / / doi.org/10.1016/j. healthplace.2014.03.003

7. Deforche B, Van DyckD, Verloigne M, De Bourdeaudhuij I. Perceived social and physical environmental correlates of physical activity in older adolescents and the moderating effect of self-efficacy. Prev Med 2010; 50(Supl. 1): S24-29. https:// doi.org/10.1016/j. ypmed.2009.08.017

8. Demographia World Urban Areas: 15th Annual Edition: 201904. Demographia. St. Louis M-IUA; 2019.

9. Greene J, Guanais F. An examination of socioeconomic equity in health experiences in six Latin American and Caribbean countries. Rev Panam Salud Publica 2018; 42: e127. https: / / doi.org/10.26633/RPSP.2018.127

10. Instituto Brasileiro de Geografia e Estatística. Coordenação de População e Indicadores Sociais. Pesquisa Nacional de Saúde do Escolar: 2015. Rio de Janeiro: IBGE; 2016. 132 p.

11. Brasil. Ministério da Saúde. Secretaria de Vigilância em Saúde. Departamento de Análise em Saúde e Vigilância de Doenças não Transmissíveis. Vigitel Brasil 2018: vigilância de fatores de risco e proteção para doenças crônicas por inquérito telefônico: estimativas sobre frequência e distribuição sociodemográfica de fatores de risco e proteção para doenças crônicas nas capitais dos 26 estados brasileiros e no Distrito Federal em 2018. Brasília: Ministério da Saúde; 2019. 132 p.

12. Van Hecke L, Loyen A, Verloigne M, van der Ploeg HP, Lakerveld J, Brug J, et al. Variation in population levels of physical activity in European children and adolescents according to cross-European studies: a systematic literature review within DEDIPAC. Int J Behav Nutr Phys Act 2016; 13: 70. https://doi. org/10.1186/s12966-016-0396-4

13. Loyen A, Van Hecke L, Verloigne M, Hendriksen I, Lakerveld J, Steene-Johannessen J, et al. Variation in population levels of physical activity in European adults according to cross-European studies: a systematic literature review within DEDIPAC. Int J Behav Nutr Phys Act 2016; 13: 72. https:// doi.org/10.1186/ s12966-016-0398-2

14. Ferrari GLM, Kovalskys I, Fisberg M, Gómez G, Rigotti A, Sanabria LYC, et al. Original research Socio-demographic patterning of self-reported physical activity and sitting time in Latin American countries: findings from ELANS. BMC Public Health 2019; 19(1): 1723. https:/ / doi.org/10.1186/ s12889-019-8048-7

15. São Paulo. Prefeitura. Plano Diretor Estratégico do Município de São Paulo. [Internet]. São Paulo: Prefeitura [accessed on Apr. 12, 2020]. Available at: https: / / www. prefeitura.sp.gov.br/cidade/secretarias/urbanismo/ legislacao/plano_diretor/index.php? $\mathrm{p}=201105$

16. Hensley M, Mateo-Babiano D, Minnery J. Healthy places, active transport and path dependence: a review of the literature. Health Promot J Austr 2014; 25(3): 196-201. https:/ / doi.org/10.1071/ he14042

17. Turi BC, Codogno JS, Fernandes RA, Lynch KR, Kokubun E, Monteiro HL. Time trends in physical activity of adult users of the Brazilian National Health System: 2010-2014. Longitudinal study. São Paulo Med J 2017; 135(4): 369-75. https: / / doi. org/10.1590/1516-3180.2017.0025190317

18. Ferreira RW, Varela AR, Monteiro LZ, Hafele CA, Santos SJD, Wendt A, et al. Sociodemographic inequalities in leisure-time physical activity and active commuting to school in Brazilian adolescents: National School Health Survey (PeNSE 2009, 2012, and 2015). Cad Saude Publica 2018; 34(4): e00037917. https:/ / doi. org/10.1590/0102-311x00037917 
19. Cesar CLG, Barros MBA, Alves MCGP, Carandina L, Goldbaum M. Saúde e Condição de Vida em São Paulo - Inquérito Multicêntrico de Saúde no Estado de São Paulo - ISA-SP. São Paulo: USP/ FSP; 2005. Resenha de Almeida MF. Ciênc Saúde Coletiva 2006; 11(4): 1131. https: / / doi.org/10.1590/ S1413-81232006000400033

20. Alves M, Escuder MML, Goldbaum M, Barros MBA, Fisberg RM, Cesar CLG. Sampling plan in health surveys, city of São Paulo, Brazil, 2015. Rev Saude Publica 2018; 52: 81. https://doi.org/10.11606/ s1518-8787.2018052000471

21. Craig CL, Marshall AL, Sjöström M, Bauman AE, Booth ML, Ainsworth BE, et al. International physical activity questionnaire: 12 -country reliability and validity. Med Sci Sports Exerc 2003; 35(8): 1381-95. https:/ / doi.org/10.1249/01.mss.0000078924.61453.fb

22. Guedes D, Lopes C, Guedes JERP. Reprodutibilidade e validade do Questionário Internacional de Atividade Física em adolescentes. Rev Bras Med Esporte 2005; 11(2): 151-8. https: / / doi.org/10.1590/ S1517-86922005000200011

23. Hagströmer M, Bergman P, De Bourdeaudhuij I, Ortega FB, Ruiz JR, Manios Y, et al. Concurrent validity of a modified version of the International Physical Activity Questionnaire (IPAQ-A) in European adolescents: The HELENA Study. Int J Obes (Lond) 2008; 32(Supl. 5): S42-48. https: / / doi.org/10.1038/ijo.2008.182

24. Hallal PC, Gomez LF, Parra DC, Lobelo F, Mosquera J, Florindo AA, et al. Lessons learned after 10 years of IPAQ use in Brazil and Colombia. J Phys Act Health 2010; 7(Supl. 2): S259-264. https:/ / doi.org/10.1123/ jpah.7.s2.s259

25. Arem H, Moore SC, Patel A, Hartge P, Berrington de Gonzalez A, Visvanathan K, et al. Leisure time physical activity and mortality: a detailed pooled analysis of the dose-response relationship. JAMA Intern Med 2015; 175(6): 959-67. https://doi.org/10.1001/ jamainternmed.2015.0533

26. Paul P, Carlson SA, Carroll DD, Berrigan D, Fulton JE. Walking for Transportation and Leisure Among U.S. Adults--National Health Interview Survey 2010. J Phys Act Health 2015; 12(Supl. 1): S62-9. https:/ / doi.org/10.1123/jpah.2013-0519

27. Garriguet D, Tremblay S, Colley RC. Comparison of Physical Activity Adult Questionnaire results with accelerometer data. Health Rep 2015; 26(7): 11-7.

28. Pitanga FJG, Matos SMA, Almeida MDC, Barreto SM, Aquino EML. Leisure-Time Physical Activity, but not Commuting Physical Activity, is Associated with Cardiovascular Risk among ELSA-Brasil Participants. Arq Bras Cardiol 2018; 110(1): 36-43. https: / / doi. org/10.5935/abc. 20170178
29. Vaara JP, Kyröläinen H, Fogelholm M, Santtila M, Häkkinen A, Häkkinen K, et al. Associations of leisure time, commuting, and occupational physical activity with physical fitness and cardiovascular risk factors in young men. J Phys Act Health 2014; 11(8): 1482-91. https: / / doi.org/10.1123/jpah.2012-0504

30. Lee S, Davis WW, Nguyen HA, McNeel TS, BrickJM, Flores-Cervantes I. Examining Trends and Averages Using Combined Cross-Sectional Survey Data from Multiple Years. CHIS Methodology Paper 2007: 1. https: / / doi.org/10.13140/RG.2.2.15153.79203

31. Guthold R, Stevens GA, Riley LM, Bull FC. Global trends in insufficient physical activity among adolescents: a pooled analysis of 298 population-based surveys with 1.6 million participants. Lancet Child Adolesc Health 2020; 4(1): 23-35. https: / / doi.org/10.1016/S2352-4642(19)30323-2

32. Guthold R, Stevens GA, Riley LM, Bull FC. Worldwide trends in insufficient physical activity from 2001 to 2016: a pooled analysis of 358 population-based surveys with 1.9 million participants. Lancet Glob Health 2018; 6(10): e1077-e1086. https:// doi.org/10.1016/ S2214-109X(18)30357-7

33. Vilhjalmsson R, Kristjansdottir G. Gender differences in physical activity in older children and adolescents: the central role of organized sport. Soc Sci Med 2003; 56(2): 363-74. https: / / doi.org/10.1016/s0277-9536(02)00042-4

34. Mielke GI, Silva ICM, Kolbe-Alexander TL, Brown WJ. Shifting the Physical Inactivity Curve Worldwide by Closing the Gender Gap. Sports Med 2018; 48(2): 481-9. https: / / doi.org/10.1007/s40279-017-0754-7

35. Sallis JF, Prochaska JJ, Taylor WC. A review of correlates of physical activity of children and adolescents. Med Sci Sports Exerc 2000; 32(5): 963-75. https:// doi. org/10.1097/00005768-200005000-00014

36. Knuth AG, Hallal PC. Temporal trends in physical activity: a systematic review. J Phys Act Health 2009; 6(5): 548-59. https:// doi.org/10.1123/jpah.6.5.548

37. Juneau CE, Potvin L. Trends in leisure-, transport-, and work-related physical activity in Canada 1994-2005. Prev Med 2010; 51(5): 384-6. https: / / doi.org/10.1016/j. ypmed.2010.09.002

38. Palacios-Ceña D, Alonso-Blanco C, Jiménez-Garcia R, Hernández-Barrera V, Carrasco-Garrido P, PileñoMartinez E, et al. Time trends in leisure time physical activity and physical fitness in elderly people: 20 year follow-up of the Spanish population national health survey (1987-2006). BMC Public Health 2011; 11: 799. https:/ / doi.org/10.1186/1471-2458-11-799

39. Stamatakis E, Chaudhury M. Temporal trends in adults' sports participation patterns in England between 1997 and 2006: the Health Survey for England. Br J Sports Med 2008; 42(11): 901-8. https:// doi.org/10.1136/ bjsm.2008.048082 
40. Hallal PC, Andersen LB, Bull FC, Guthold R, Haskell W, Ekelund U, et al. Global physical activity levels: surveillance progress, pitfalls, and prospects. Lancet 2012; 380(9838): 247-57. https://doi.org/10.1016/ s0140-6736(12)60646-1

41. Brasil. Ministério da Saúde. Secretaria de Vigilância em Saúde. Secretaria de Atenção à Saúde. Política Nacional de Promoção da Saúde. Brasília: Ministério da Saúde; 2010.

42. Malta DC, Oliveira TP, Santos MA, Andrade SS, Silva MM, Grupo Técnico de Monitoramento do Plano de D. Progress with the Strategic Action Plan for Tackling Chronic Non-Communicable Diseases in Brazil, 2011-2015. Epidemiol Serv Saúde 2016; 25(2): 373-90. https: / / doi.org/10.5123/ s1679-49742016000200016

43. Brasil. Ministério da Saúde. Secretaria de Vigilância em Saúde. Plano de ações estratégicas para o enfrentamento das doenças crônicas não transmissíveis (DCNT) no Brasil: 2011-2022. Brasília: Ministério da Saúde; 2011.
44. Reis RS, Yan Y, Parra DC, Brownson RC. Assessing participation in community-based physical activity programs in Brazil. Med Sci Sports Exerc 2014; 46(1): 92-8. https: / / doi.org/10.1249/MSS.0b013e3182a365ae 45. Ferrari GLM, Kovalskys I, Fisberg M, Gomez G, Rigotti A, Sanabria LYC, et al. Anthropometry, dietary intake, physical activity and sitting time patterns in adolescents aged 15-17 years: an international comparison in eight Latin American countries. BMC Pediatr 2020; 20(1): 24. https: / / doi.org/10.1186\%2Fs12887-020-1920-x

Received on: 08/13/2020

Revised on: 01/24/2021

Accepted on: 02/22/2021

Authors' contribution: all the authors participated in the conception and design, analysis and interpretation of data, writing of the article, critical review of the intellectual content and final approval of the version to be published. 